\title{
Workplace wellbeing, avagy a modern kori munkahely Workplace well-being, or the workplace of the modern age
}

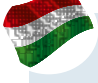
ÖSSZEFOGLALÁS:

A modern kori életünk nem csak a modern technológiától az, ami. A modern kor paradigmaváltást is megkíván a gondolkodásunkban, az életünk szinte minden területén. Ha végignézzük a sok-sok technológiai vívmányból fakadó változást, valamint az ezzel együtt alakuló társadalmi berendezkedéseket, akkor okkal mondhatjuk, hogy már semmi sem úgy múködik, mint akár tíz, húsz évvel ezelőtt. Jelen tanulmány annak a közösségnek a múködését vizsgálja, amelyben a felnőtt emberek napjuk nagy részét töltik. Ez pedig a munkahely. A tanulmány rávilágít a modern kori, inspiratív és ösztönző munkahelyek mibenlétére, egyfajta irányt mutatva a változáshoz, változtatáshoz.

Kulcsszavak: workplace wellbeing, paradigmaváltás, balancer, stresszor, munkahelyi környezet

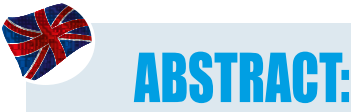

Our modern life is not just what modern technology is all about. The modern age also requires a paradigm shift in our thinking in almost every area of our lives. If we look at the change resulting from many, many technological achievements, as well as the social arrangements that develop along with it, we can say for a reason that nothing works the way it did ten or twenty years ago. The present study examines the functioning of the community in which adults spend most of their day. And this is the job. The study sheds light on the nature of modern, inspiring and stimulating workplaces, showing a kind of direction for change.

Keywords: workplace wellbeing, paradigm shift, balancer, stressor, working environment

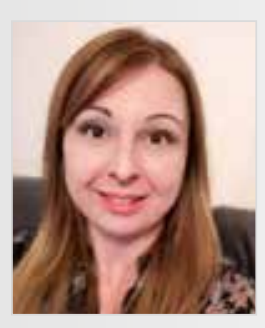

Szerzö, rovatvezető: MATÓ-JUHÁSZ ANNAMÁRIA Miskolci Egyetem Gazdaságtudományi Kar Whole life balance specialista efkegtur@uni-miskolc.hu egyetemi tanársegéd, Ph.D hallgató Kutatási terület: Az egészségtudatos magatartás fejlesztése a társadalmi marketing eszközeivel juhasz.ancsa@uni-miskolc.hu

\section{BEVEZETÉS}

A modern társadalmakban központi szerepet tölt be a munka. A munka szabja meg társadalmi identitásunkat és státuszunkat, mi több, a munka jelenti jövedelmünk elsődleges forrását. Lehetőséget nyújt a tanuláshoz és a fejlődéshez, a sikerhez és az elégedettséghez, valamint széles körü társas kapcsolatok építéséhez. Azáltal, hogy eleget teszünk a munkánk által előírt elvárásoknak és a követelményeknek, növekedhet énhatékonyságunk is (Valló -Nemes, 200o). Mindezek odáig vezettek, hogy az elmúlt években a munkahelyi stressz okozta egészségi problémák emelkedő tendenciát mutattak. „A WHO évekkel ezelőtti előrejelzése szerint már 2020-ra a depresszió lesz a munkaképtelenség második leggyakoribb oka” (Juhász, 2002).

„A munkahelyi egészségfejlesztésnek nevezett eljárás nem csak arra irányul, hogy feltárja, majd kiküszöbölje a munkavállalók egészségére leselkedő veszélyeket, s ily módon megelőzze az egészség romlását, vagyis a betegség kialakulását. Emellett a munkavállalókat megpróbálja aktív részesévé tenni önmaguk egészségi állapotának alakításában. Ehhez kíván minél több lehetőséget biztosítani, alapul véve a folyton változó igényeket és szakmai hátteret” (Fritz; 2011).

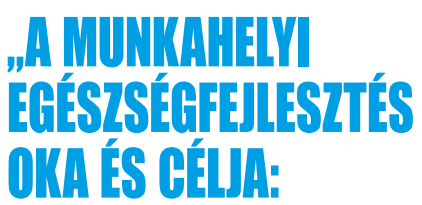

A munkahelyi egészségfejlesztési programok megjelenésének elsődleges kiváltó oka a dolgozók betegsége miatt a munkáltatókra nehezedő költségek radikális megnövekedése volt. Egyes országokban (pl. USA) a munkáltató fizeti dolgozói és azok családtagjainak egészségbiztosítását. De azokban az országokban is, ahol ez nem így van, a dolgozók hiányzása jelentős költségeket ró a vállalatokra. A programok célja tehát elsősorban a dolgozók egész- ségének javításán keresztül e költségek csökkentése volt. Időközben azonban kiderült, hogy a munkahelyi egészségfejlesztési programoknak a fentieken kívül egyéb kedvező hatásai is vannak, melyek közvetett módon szintén javíthatják a vállalat eredményességét és külső megítélését" (Fritz; 2011).

A COVID-19 pandémia a tényleges megbetegedések mellett a munkahelyi körülmények megváltozását és/ vagy a munkahelyek elvesztését eredményezte. A megélhetési problémákról pedig nem is beszélve. A pandémia sok mindenre rámutatott. Többek között arra, hogy a világunk fenntartható múködése akkor érhető el, ha a WHO által már évek óta kimondott egészségre, mint a fenntartható fejlődés alapjára építjük azt. Ez azt a közgazdasági irányt is hivatott felerősíteni, ami az emberközpontú gazdaság néven ismert. Ez azt jelenti, hogy a gazdasági folyamatok az ember szempontjai szerint, az ember érdekeivel és méltóságával összhangban szerve- 
ződnek, hiszen a magánszemélyek és a vállalkozások csak akkor boldogulhatnak, ha a gazdaság nekik, értük dolgozik. A pandémia okozta változások, az innovációk, a technikai fejés erőteljesen kapcsolódnak a fogyasztók megváltozott szokásaihoz. Ez együtt alapjaiban megváltoztatja gondolkodásunkat, az értékrendünket és a napi tevékenységeinket (Európai Alapítvány az Élet- és Munkakörülmények Javításáért, 2021).

Ahhoz, hogy a megváltozott világunkat egy kvázi biztonságos, fenntartható módon vigyük tovább, arra a kérdésre kell a választ megtalálni, hogyan lehet az embert mint megújuló erőforrást értelmezni?

Újfajta értékrend van kialakulóban, amelyben a jóllét fogalomköre kerül előtérbe. A jóllét sokkal inkább örömöt, biztonságot, egészséget, közösségeket takar. Ahogy a Föld erőforrásaival való bánást is át kell értelmeznünk, fontos megtennünk ugyanezt a munka világában is. Magyarán a dolgozók erőforrásainak legyen szó az érzelmi, szellemi, fizikai kapacitásukról - optimális kihasználesztések széles körben elterjednek

\section{KUTATÁSI KÉRDÉS}

lása a cél, sem az unatkozás, sem a túlterhelés nem fenntartható állapot.

A fenntarthatóság fogalomköre fejlődést jelent, és nem növekedést, amelyre nem várni kell, hogy majd megjelenik, hanem abba tudatosan át kell állni. A tudatos döntés pedig bizonyos elvek mentén történik minden szereplő részéről.

Tudatos döntéshozatal akkor történik, amikor az ember tudatában van, és tisztán látja a saját maga müködési mechanizmusát, valamint azt a hatást, amit a környezetére tesz, illetve a környezete tesz saját magára. Ennek a tudatosítására már 2016-ban megalkotásra került a Holisztikus egészségtudatosság fenntartható modellje, amely nagyobb hangsúlyt fektet az egyén és a környezetének kapcsolatára. A modell több szempontból is holisztikus.

- Elsősorban a test-lélek-szellem harmóniájából indul ki az egyén szintjén. Ennek a hármas egységének a folyamatos egyensúlyban tartásaként, azaz pillanatnyi állapotok egymásutánjaként értelmezi az egészségi állapotot.

- Másodsorban a modell holisztikus, mivel tartalmazza azokat a tár-

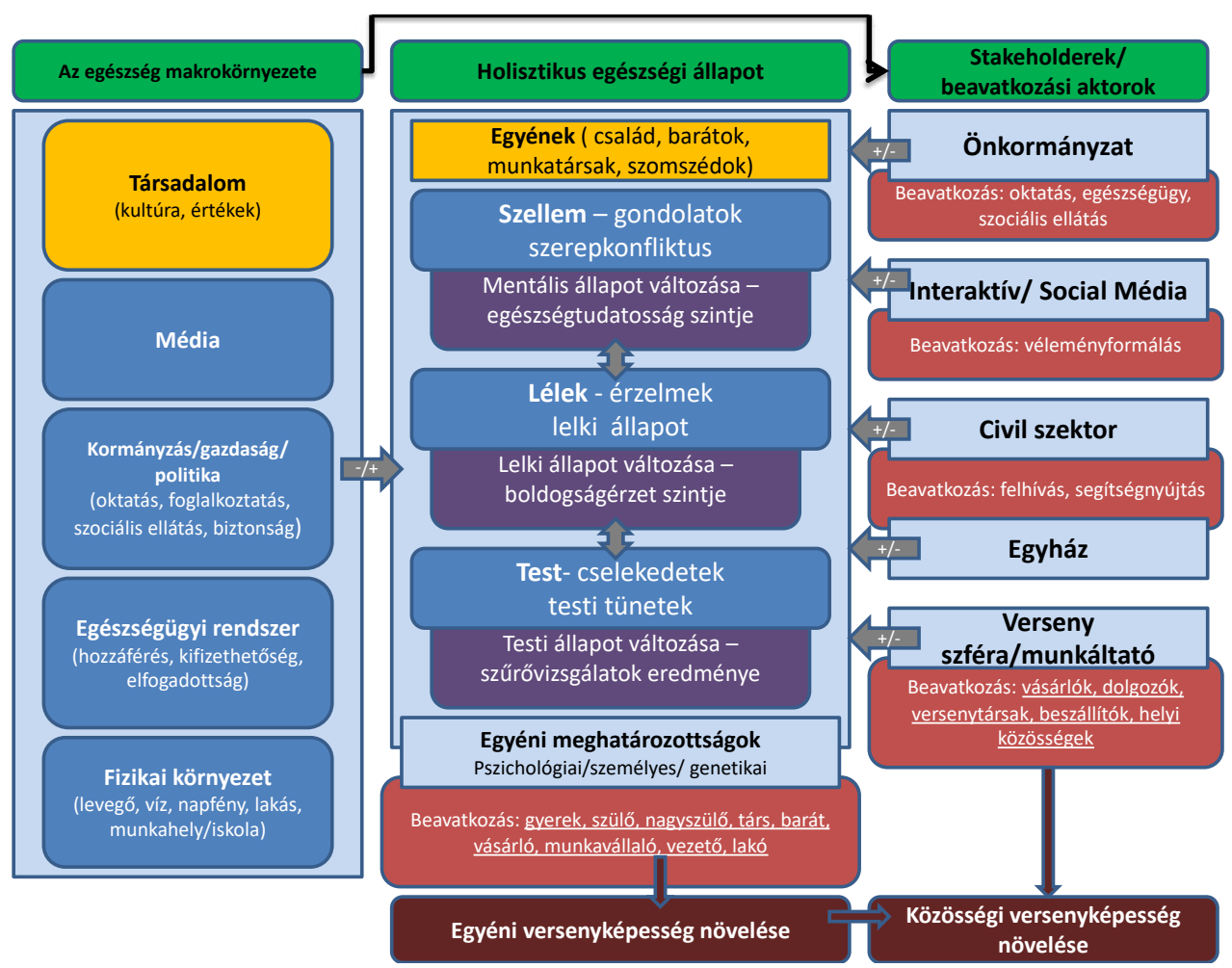

1. ábra: A holisztikus egészségtudatosság fenntartható modellje Figure 1: Holistic health model of sustainable development Forrás/Source: Mató-Juhász et al. (2016, 227-239. 0.) sadalmi stakeholdereket, amelyek képesek az egyéni egészséget befolyásolni, sőt abba beavatkozni is (balancerként, vagy stresszorként), így társadalmi aktorrá válni.

A modell teljes értelmezésétól jelen tanulmányban eltekintünk, kizárólag az egyén és a munkáltató aspektusait vesszük górcső alá a felelősségvállalás irányából vizsgálva azt. Az elmúlt évek egészségtudatossági trendjei, valamint a COVID-19 pandémia új képességek használatát erősítette fel a hatékony túlélés érdekében. Ezek a következők: mentálhigiénia, pozitív pszichológia, asszertív kommunikáció, médiatudatosság, önmarketing, reziliencia, hatékony életvezetés, multitasking szemlélet. Amennyiben felelősségteljes és tudatos döntésről beszélünk a fent említett két szereplő esetében, akkor a következő definícióval élhetünk.

Egyéni szinten a felelős és tudatos magatartás: napi szinten tesz a testi-lelki-mentális épségéért rekreációs tevékenységekkel; másokat is motiváló, inspiráló, pozitív kommunikációt folytat mind személyesen, mind pedig az online térben; ugyanolyan fontos számára a természeti környezet, illetve a társas kapcsolatok.

Munkáltatói szinten a felelős és tudatos magatartás: Támogató munkahelyi környezet biztosítása, azaz balancerként múködni streszszor helyett.

Ahhoz, hogy egy munkahely támogató, balancer legyen, több öszszetevő összehangolása szükséges. A munkahelyi jólléti index 2020-ban került összeállításra az Egyesült Királyságban, ahol nagyon gyorsan reagáltak a megváltozott világunkból származó kihívásokra. Ebben az indexben kifejezetten a mentális egészségre gyakorolt hatást helyezik a középpontba. Öt témakört vizsgálnak, ezek a következők: szervezeti kultúra és elkötelezettség, jólléti szolgáltatások, tudás/tudatosság és készségek, people management, támogató csomag. Mindezek vizsgálatán túl egy elvet is megfogalmaznak. A munkahelyi mentális egészséggel kapcsolatos bevált gyakorlatokat be kell építeni a vállalat müködési modelljének minden elemébe. 
Ehhez első lépésként összeállításra kell, hogy kerüljön egy Jóllét stratégia. A modell öt alapelvet fogalmaz meg a munkahelyi mentális egészség fenntartható javítása érdekében, azaz a stratégia hatékony összeállítására (Carmichael et al, 2021).

1. Átfogó elemzés - amely beazonosítja azokat a kockázatokat, amelyek stresszorként megjelenhetnek a munkahelyen.

2. Integrált és holisztikus szemlélet - Emberek, Folyamat, Szervezet, Kultúra estében, több dimenzióban beazonosítani a beavatkozási pontokat.

3. A kultúra és múködési modellváltás ösztönzésében nem csak az számít, hogy mi változik; aki végrehajtja a változást, szintén kritikus. Ezért a kulcsemberek, hatásközpontok kijelölése és/vagy kiemelése elengedhetetlen.

4. A beavatkozások személyre szabottak, így sablonmegoldások munkakörök esetében sem biztos, hogy automatikusan alkalmazhatóak.

5. A feladat a közösséggel együtt oldható csak meg, azaz mindenki bevonása meg kell, hogy történjen.

A stratégia után a kivitelezés a második lépés. Vezetői tréning program és Jóllét webinar segítségével edukálni kell az érintetteket és napi gyakorlatba ültetni a változásokat. Érdemes a fejlesztési eszközökhöz olyan módon nyúlni, hogy azzal ne újabb erőforrásokat kelljen bevonnunk, hanem a meglévóket tudjuk hatékonyabban használni, valamint kiiktatni idő- és energiarabló tényezőket.

Ezzel a szemléletmóddal megkerülhetők pl. a felesleges adminisztrációs körök, a kizsigerelt munkavállalókból pedig elkötelezett kollégák válhatnak.

A fejlődés útján alkalmazhatjuk az apró lépések technikáját, valamint az olyan kommunikációs stratégiákat, amelyek segítik az elköteleződést a jó ügyek mellett.

\section{KOMKLIÚzló}

A modern korban, annak technikai vívmányait alkalmazva, akkor lehet igazán hatékonyan egészséges életstílust folytatni, ha azok az alábbi pillérekre építkeznek.
- Holisztikus szemlélet - az egyén egyrészt figyel a saját testi-lelki-mentális egyensúlyára, másrészt figyel a többi ember testi-lelki-mentális épségére mind személyesen, mind az online térben, továbbá ugyanúgy figyel a természeti környezet és az ember kölcsönhatásaira.

- Természeti környezet - az egyén ismeri és tiszteli a bolygót, a flórát és a faunát, valamint ezek jótékony, élettani gyógyító hatását.

- Határok - az egyén le tudja fektetni a saját határait a különböző szerepeiben és életszakaiban, azokat be tudja tartatni a megfelelő kommunikációval és viselkedéssel mind személyesen, mind pedig az online térben.

- Minta - az egyén tudja vagy képes beazonosítani azokat a mintákat, melyek a szocializációja során rárakódtak, és képes ezeken változtatni is a saját hatékonyabb, boldogabb életminősége, életének kiteljesítése érdekében. Ezt akár önállóan, akár támogatással valósítja meg.

- Időmenedzsment - az idővel való gazdálkodás a tekintetben kerül itt elő, amely azt mutatja meg: hogy kire és mire szeretne valaki időt áldozni. Az egyén tudja, hogy mit jelent a toxikus kapcsolatok fogalma, és tisztában van azzal is, hogy ezek milyen hatással vannak a jóllétére, így az alapján osztja be az idejét, hogy hol és kivel érzi jól magát.

Mindezek ismeretében a modern kori munkahely akkor lesz támogató, balancer, ha ott

- Holisztikus szemléletű egészségfejlesztés történik (közösségi programok identitásépítéssel társulnak)

- Vezetői képességek fejlesztése folyamatos (coaching szemlélet)

- Az egyéni ellenálló képesség javítása folyamatos (Modern Healthy Lifestyle program - mozgás, táplálkozás, reziliencia, életpálya, csapatmunka erősítése)

- Közösségi épület, közösségi tér olyan, amely a természetből származó balancereket biztosítja (levegő, víz, napfény, növények, színek, illatok, berendezések, szórakoztató csapattevékenységek)

- Fokozott rugalmasság figyelhető meg (rugalmas munkaidő, további fizetett és fizetés nélküli szabadidőt, csökkentett órákat vagy megváltozott munkarendeket, digitális detox)

- A munkaterhelés felügyelete és a dinamikus újraegyensúlyozás folyamatosak (rekreációs tevékenységek ösztönzése, asszertív, szeretet kommunikáció)

„A munkahelyi egészségfejlesztés nem csupán egy hosszú folyamat elindítását jelenti, hanem a lehető legtöbb szintéren a többirányú, egymás mellett párhuzamosan futó, munkavállalói igényt kielégítő és a társaság lehetőségeit kihasználó komplex programcsomag, mely a társaság vezetése által támogatott, valamint szakmailag felügyelt kell legyen.

Ezen feltételek megléte esetén tud a munkavállalók mindennapi tevékenységének részévé válni" (Fritz, 2011).

A fent leírásra került logika mentén a paradigmaváltás vezetôi szinten indul, és sokkal összetettebb folyamat, mint eddig azt gondoltuk. Azonban látható, hogy a fenntartható gazdaság és a boldog élet alapja a tudatos, felelős döntéshozatal, bármilyen szereplőről és szerepről legyen is szó.

A jobb élet kialakítása közös ügyünk, aminek elkezdéséhez nincs jobb időpont a mostnál.

\section{IRODALOMJEGYZÉK}

Carmichael, A. - Lander, F. - Steele, R. (2021): Out of the shadows: Sustainably improving workplace mental health From: https://www.mckinsey.com/featured-insights/asia-pacific/out-of-the-shadows-sustainably-improving-workplace-mental-health

Európai Alapítvány az Élet- és Munkakörülmények Javításáért (2021), From: https://www.eurofound.europa.eu/hu/ topic/working-conditions-and-sustainable-work

Fritz, P. (2011): Munkahelyi egészségfejlesztés. IN: Fritz. P. (szerk.): Mozgásos rekreáció. Bába Kiadó, Szeged, 276-284. o.

Juhász, Á. (2002): Munkahelyi streszsz, munkahelyi egészségfejlesztés, From: http://munkahelyiegeszsegfejlesztes.hu/ docs/doc2.pdf

Mató-Juhász, A. - Kiss-Tóth, E. - Szegedi, K. (2016): Holistic Health Model Of Sustainable Development, EUROPEAN SCIENTIFIC JOURNAL 12 : 21 pp. 227-239., 13 p.

Valló, Á. - Nemes, J. (2000): Menedzserbetegségek, B+V (medical\&technical) Lap és Könyvkiadó Kft., 16.17.18.19.20.21. 